\title{
COMPARISON BETWEEN RING AND COMPACT SPUN FROM LONG STAPLE EGYPTIAN COTTON VARIETIES Elayan, Sohair E. D. ${ }^{1}$; Amany M. Abdalla ${ }^{1}$; Nafisa T. Ahmed ${ }^{2}$ and Eman R. El-Sayed ${ }^{2}$ \\ 1- Agronomy Dept., Faculty of Agriculture, Cairo University, Egypt. \\ 2- Cotton Research Institute, Agriculture Research Center, Giza, Egypt
}

\begin{abstract}
This study has been done to compare ring and compact yarns spun from Egyptian long staple varieties .six long staple cotton varieties were used as Giza 80 , Giza 83, Giza 90, Giza 85, Giza 86 and Giza 89 ,chosen to produce 40's count yarn spun at three different twist multiplier;3.2, 3.6 and 4.0. The obtain data cleared that:The compact spun yarns at low twist level had better yarn property values - thin and thick places, nep values, yarn hairiness, yarn evenness, yarn strength and elongation at break (\%) - than the conventional ring spun yarns for long staple Egyptian cotton varieties in the same twist level .i.e. yarn strength of the compact yarn was $11 \%$ higher than the conventional ring spun yarn. In addition, Compact yarns reached maximum strength at a lower twist multiplier than conventional ring yarns. Increasing twist caused a reduction in the number of thin and thick places and yarn hairiness in both compact and ring yarns While Elongation at break and Strength values increased with higher twist for both spinning systems. The data revealed that, Giza 86 variety was superior in fiber strength (cN/tex) and Giza 90 variety was superior in yarn evenness and hairiness values than other varieties.
\end{abstract}

\section{INTRODUCTION}

During the last two decades, components of ring spinning machines have been greatly improved changes in drafting system; drive systems and robotics have enabled large gains in productivity, flexibility and quality. Most of the technical advances in ring spinning were aimed at improving the performances on the existing technology.

In recent years, another innovation, "Compact or condensed spinning has gained momentum because it minimizes width and height of the spinning triangle associated with ring spinning. Compact spinning technology has been gaining much more interest since its first commercial introduction at ITMA-Paris in 1999 as shown in graph 1. These spinning machines have been installed in several spinning factories all over the world consequently, in Egypt Compact spinning is a modified ring spinning process which has special advantages, and can be used in both short- and long-staple yarn spinning areas. The mechanism of Compact spinning is narrowing and decreasing the width of the band of fibers which come out from the drawing apparatus before it is twisted into yarn, and the elimination of the twisting triangle. This causes the fiber stream in the form of the flat band of fibers to be condensed into a compact fiber stream with increased the attached points between the fibers. 


\section{Operating principle}

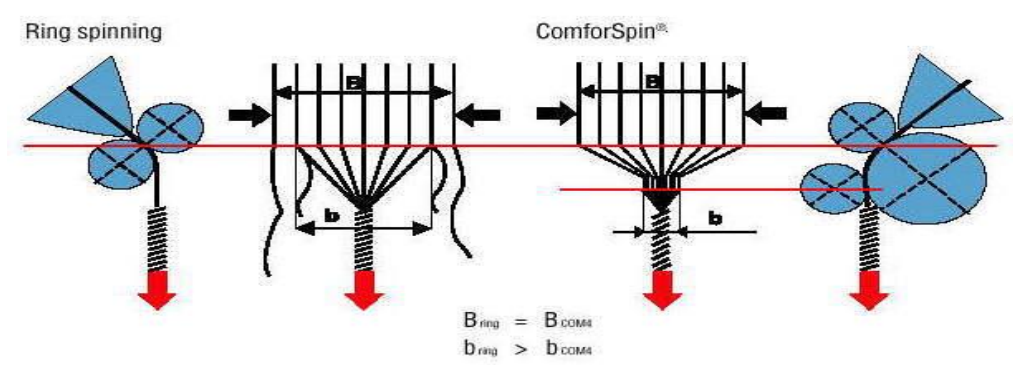

\section{Graph 1. Yarn formation in conventional and compact ring spinning}

Many investigators reported about comparison between ring and compact spun system such as Celik and Kadoglu (2004) in compact yarns, fibers are uniformly oriented and joined into the yarn right after the end of the drafting arrangement. Therefore, better tenacity, elongation, and hairiness properties can be ensured. The better tenacity properties of compact spun yarn provide opportunities to work with lower twist coefficients, resulting in an increase in production rate, and also better handling properties of the endproduct. Another advantage of the compact spun system is the fly and dust reduction as an effect of condensation

Compact spinning is effectively improve yarn quality and enhance its performance during the downstream processing phase. This was asserted by numerous authors (Artzt et al. (1995), Artzt (2000), Olbrich (2000), Stahlecker (2000), Stalder (2000) and Stalder and Rusch (2002))

Krifa et al. (2002) compact spinning systems offer the possibility of using cottons with shorter staple lengths to produce high-quality yarns that heretofore required long- or extra-long-staple cottons.

Ahmad (2004) in compact yarn, strength is higher by about $15 \%$ and elongation at break by about $20 \%$ compared with that of conventional yarn. Compact spun yarns also have better abrasion resistance of about $25 \%$ .fabric properties in terms of breaking strength, breaking elongation and tear strength are also better with compact yarn.

Basal and Oxenham (2006) showed that the high tenacity values of compact yarns can be attributed to the higher rate and amplitude of fiber migration in these yarns compared to those in conventional ring yarns. Another important finding was the superiority of compact yarns in terms of tensile properties is less noticeable at higher twist levels.

Krifa and Etbridge (2006) reported that compact spinning has been shown to significantly improve yarn tensile properties and reduce its hairiness. Both characteristics are crucial for yarn performance in downstream manufacturing operations.

Sanad and El-Sayed (2006) reported that the yarns spun on the compact spinning system are characterized by higher tenacity, higher elongation at break, and significantly lower hairiness in comparison with yarns spun on the conventional ring spinning frame. For the long staple 
Egyptian cotton varieties, the breaking force or single yarn strength of the compact yarn (40 Ne spun from long staple cottons) was 17.63 higher than the conventional ring spun yarn. This means that, the compact spinning system is more useful for long staple cottons and coarse and medium counts than for the extra long staple cottons and finer counts. The aim of the investigation is to comparison between ring and compact yarns spun form long staple Egyptian cotton varieties.

\section{MATERIALS AND METHODS}

The present study was carried out in Cotton Research Institute, Pilot Spinning Mill, at 2005 season. six Long-Staple commercial cotton varieties namely Giza 80, Giza 83, Giza 85, Giza 86, Giza 89, and Giza 90 were selected to produce $40 \mathrm{~s}$ count yarns spun at three different twist multipliers 3.2, 3.6 and 4.0. The yarns were produced in both compact and conventional ring spinning. The compact carded yarns processed under comparable technological conditions on the RST1 Marzoli ring and compact spinning fitted with "Olfil System" on one frame in the Pilot Spinning Mill. The processing outline presented in Table (1). Cotton fiber properties were determined according to ASTM method (1991) by using HVI Spectrum and Micromat and the data were presented in Table (2).

Table (1): processing outline for the cottons under study (A) Ring and Compact carded yarns.

\begin{tabular}{|c|c|}
\hline Cotton category & Long-Staple cottons \\
\hline $\begin{array}{l}\text { Region and Cotton } \\
\text { varieties }\end{array}$ & $\begin{array}{l}\text { Upper Egypt varieties (Giza 80, Giza } 83 \text { and Giza 90) } \\
\text { Delta cottons varieties (Giza 85, Giza } 89 \text { and Giza 86) }\end{array}$ \\
\hline Roving Frame & BCX 16-A Marzoli \\
\hline Roving count & 0.90 hank \\
\hline Ring spinning frame & RST 1 Marzoli \\
\hline Spindle speed (rpm) & 16000 \\
\hline Yarn count $(\mathrm{Ne})$ & 40 \\
\hline Twist multiplier & 3.6 \\
\hline Ring diameter $(\mathrm{mm})$ & 45 \\
\hline
\end{tabular}

Table (2): Fiber parameters for Long Staple cotton varieties.

\begin{tabular}{|l|c|c|c|c|c|c|}
\hline Variety Fiber parameters & G.80 & G.83 & G.90 & G.85 & G.89 & G.86 \\
\hline $\begin{array}{l}\text { HVI measurement } \\
\text { UHM. (mm) }\end{array}$ & 31.0 & 30.6 & 30.1 & 30.2 & 32.5 & 33.0 \\
\hline U.I. (\%) & 85.2 & 85.0 & 85.0 & 86.0 & 85.9 & 87.0 \\
\hline Short Fiber Index & 8.9 & 9.3 & 7.9 & 6.4 & 6.5 & 7.0 \\
\hline Strength (g/tex) & 38.2 & 35.5 & 35.0 & 38.5 & 42.0 & 45.0 \\
\hline Elongation \% & 7.9 & 7.6 & 7.8 & 6.4 & 7.0 & 7.0 \\
\hline Micronaire & 4.6 & 4.5 & 4.1 & 3.9 & 4.5 & 4.4 \\
\hline Maturity (\%) & 0.94 & 0.92 & 0.94 & 0.91 & 0.97 & 0.94 \\
\hline $\begin{array}{l}\text { Micromat measurement } \\
\text { Fineness (mtex) }\end{array}$ & 165 & 159 & 153 & 143 & 161 & 160 \\
\hline Maturity ratio & 83 & 85 & 83 & 85 & 87 & 87 \\
\hline
\end{tabular}


Elayan, Sohair E. D. et al.

The Statimat ME Automatic Tensile tester was used to measure single yarn mechanical properties. i.e. yarn strength $(\mathrm{CN} / \mathrm{Tex})$ and Elongation at break(\%) with 120 breaks per sample, Test length was $50 \mathrm{~cm}$ and time to break was 5 seconds. Yarn evenness (CV \%), hairiness and imperfections values were measured on Uster Tester 3 (the measurement length was 400 $\mathrm{m} /$ bobbin). The three factors (varieties, twist multiplier and spinning systems) were arranged in a completely randomized blocks design with three replicates. The obtained data were analyzed statistically according to procedures described by Gomez and Gomez (1984) for analysis of complete randomized blocks design (factorial analysis). L.S.D at $5 \%$ level of significance was compared to differentiate between means.

\section{RESULTS AND DISCUSSION}

\section{Yarn properties:}

Yarn strength and elongation

Data in Table (3) showed the comparison between ring spinning and compact spinning, the data recorded significant effect on yarn properties except elongation at break. Compact spinning system gave the highest mean values of yarn strength $(22.30 \mathrm{cN} / \mathrm{Tex})$ while ring spinning recorded the lowest mean values of yarn strength (19.98 CN/Tex). This means that, the compact yarns had better yarn property than the conventional ring spun yarns for Long Staple Egyptian cotton varieties. These data were harmony confirmed with Ahmad (2004), Basal and Oxenham (2006), Krifa and Etbridge (2006) and Sanad and El-Sayed (2006)

\section{Yarn evenness}

Data presented in Table (3) showed that the differences in mean values of yarn evenness, number of thin places, thick places and neps were significant due to the effect of spinning systems (ring spinning and compact spinning) ring spinning recorded the highest mean values of yarn evenness (C.V. \%) of (18.05\%), number of thin places(59), thick places(211) and neps (218) compared with the compact spinning, the mean values of yarn evenness(16.88) thin places(31) thick places (108), neps (115) and hairiness (4.89). this means that ,compact recorded the better imperfections values than ring spinning.

Table (3): Ring vs. compact $40 \mathrm{Ne}$, yarn properties

\begin{tabular}{|c|c|c|c|c|c|c|c|}
\hline \multirow{2}{*}{$\begin{array}{c}\text { Spinning } \\
\text { systems }\end{array}$} & $\begin{array}{c}\text { Strength } \\
\text { (C.N./ Tex) }\end{array}$ & $\begin{array}{c}\text { Elongation } \\
(\%)\end{array}$ & $\begin{array}{c}\text { CV } \\
(\%)\end{array}$ & $\begin{array}{c}\text { Thin } \\
\text { places }\end{array}$ & $\begin{array}{c}\text { Thick } \\
\text { places }\end{array}$ & $\begin{array}{c}\text { No. of } \\
\text { Neps }\end{array}$ & Hairiness \\
\hline Ring & 19.98 & 5.31 & 18.05 & 59 & 211 & 218 & 5.09 \\
\hline Compact & 22.30 & 5.34 & 16.88 & 31 & 108 & 115 & 4.89 \\
\hline LSD at 0.05 & 0.30 & N.S & 0.26 & 4.43 & 9.87 & 9.38 & 0.12 \\
\hline
\end{tabular}




\section{Yarn hairiness}

Regarding to data presented in Table (3), it could be seen that the differences in the hairiness value were significant ring spinning recorded the highest mean value(5.09)while, compact spinning recorded the lowest mean value(4.89)this means that compact spinning achieved maximum yarn hairiness reduction .

\section{Twist multiplier}

Data presented in Table (4) and demonstrated in Figure (1) showed that the effect of interaction between twist multiplier and spinning system on single yarn properties. The data obtained significant differences at 0.05 level of probability on yarn properties except number of neps. Compact yarn at4 twist multiplier recorded the highest mean values of yarn strength (24.80 $\mathrm{CN} / \mathrm{Tex}$ ) and elongation at break (5.5\%) while ring yarn at 4 twist multiplier recorded the lowest mean values of evenness and imperfection properties. Yarn strength of the compact yarn and elongation at break higher than the conventional ring spun yarn. In addition, Compact yarns reached maximum Strength at a lower twist multiplier than conventional ring yarns in the same twist multiplier. In this respect, the single yarn strength spun from Ring spinning at 4.0 twist multiplier gave the same result and higher, when spun from Compact spinning at 3.6 twist multiplier, as illustrated in Figure(1)This means that compact spinning reduced twist multiplier (10\%) while maintaining same strength, reduced yarn evenness and imperfection properties. The difference between the hairiness values of compact and ring yarns decreased as twist increased.

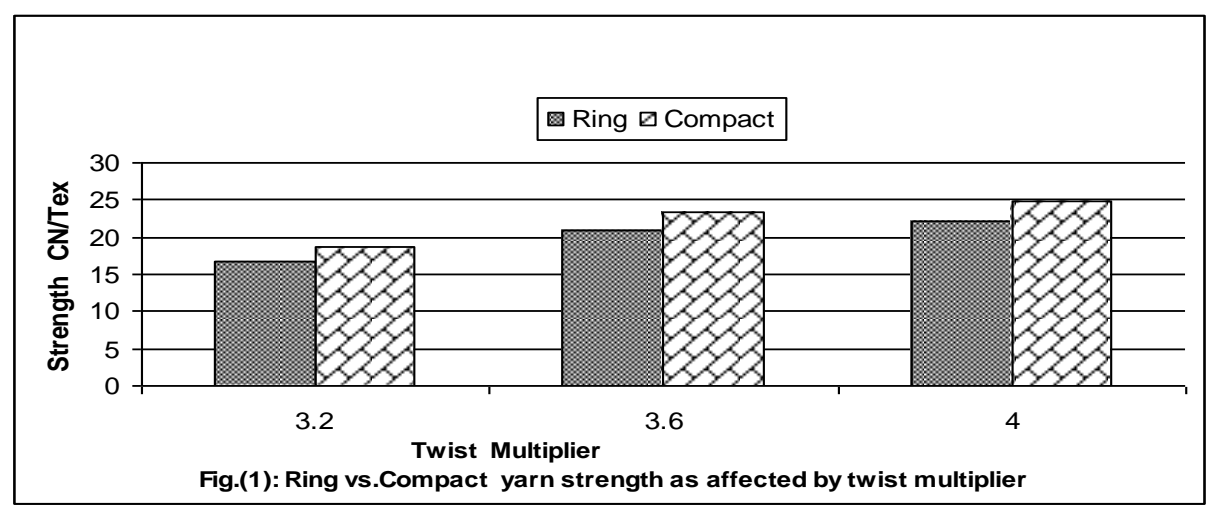

Data presented in Table (5) and demonstrated in Figure (2.3.4) showed that the interaction between Varieties, twist multiplier and spinning systems. The data recorded a significant differences effect on yarn properties. the mean values of yarn strength (cN/Tex) and elongation at break(\%) were increased as twist multiplier increased from 3.2,3.6 to 4 with the compact spun yarns. while yarn evenness, yarn hairiness, number of thin places, thick places and neps were decreased when twist multiplier increased from 3.2,3.6 to 4 with the compact spun yarns for all the varieties under study. 
Elayan, Sohair E. D. et al. 
Generally, the compact spun yarns at low twist level had better yarn property values than the conventional ring spun yarns. The data revealed that, Giza 86 variety was superior in fiber strength ( $\mathrm{cN} / \mathrm{tex})$ and Giza 90 variety was superior in yarn evenness and hairiness values than other varieties (Fg. 2,3 and 4)



\section{REFERENCES}

Ahmad, M.M. (2004) Compact spinning and advantages of Elite yarns. Pakistan Textile J., Feb.

Artzt, P. (2000) The special structure of compact yarns - advantages in downstream processing. Reprinted from the Proceedings of the Beltwide Cotton Conference Volume 1:798-803 National Cotton Council, Memphis TN.

Artzt, P.; D. Betz; J. Schneider and E. Sonntag (1995) Innovations in the ring spinning sector. Melliand International: No. 1: $31+, 3$ pages (Mar. 1995).

ASTM. (1991) American Society for Testing and Materials. Standards of textile testing and materials;Philadelphia,pa.

Basal, G. and W. Oxenham (2006) Comparison of properties and structures of compact and conventional spun yarns. Textile Res. J. 76:567

Celik, P. and H. Kadoglu (2004) A Research on the compact spinning for long staple yarns. Fibres and Textiles in Eastem Europe, October/ December, vol. 12 , 4(48):27-31

Gomez, K. A. and A. A. Gomez (1984) Statistical procedures for Agricultural Research $2^{\text {nd }}$ Ed. pp 680, John willey and sons $1^{\text {nc }}$, New York.

Krifa, M. and D. Ethridge (2006) Compact spinning effect on cotton yarn quality: Interactions with fiber characteristics. Textile Topics (3): (summer 2006)

Krifa, M.; E. Hequet and D. Ethridge (2002) Compact spinning: new potential for short staple cottons. Textile Topics (2):2-8 (spring 2002)

Olbrich, A. (2000) The AIR-COM-TEX 700 Condenser ring spinning machine. Melliand International, 6 (1): 25-29.

Stahlecker, F. (2000) Compact or condensed spinning: A Market Niche or the summit of ring spinning. Melliand International: 6 , No. 1: $30+, 3$ pages (Mar. 2000).

Stalder, H. (2000) New spinning process com for spin. Melliand International: 6, No. 1:22+, 3 pages (Mar. 2000).

Stalder, H. and A. Rusch. (2002). Successful compact spinning process. International Textile Bulletin: 48, No. 1: 42+, 2 pages (Mar. 2002).

Sanad, Suzan, H. and M. A. M. El- Sayed. (2006). The Impact of new spinning technologies on the Egyptian Cottons. Agric. Res. Rev. Egypt $84(4): 1253-1264$ 
مقارنة بين خواص جودة الخيوط المغزولـة من أقطان مصرية طويلـة التيلة على التى

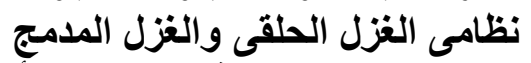

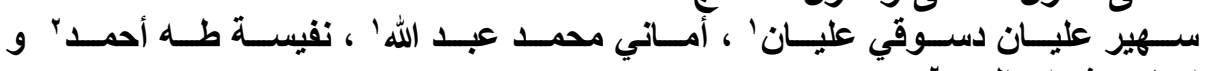

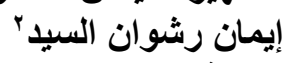

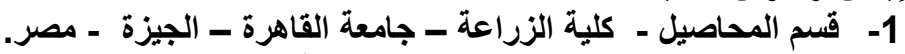
2- معهد بحوث القطن - مركز البحوث الزراعية ـ الجيزة ـ مصرة.

أجريت هذه الدراسة لدقارنة نظامى الغزل الحلقى والغزل الددمج للخيوط الدغزولة من

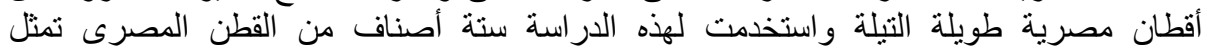

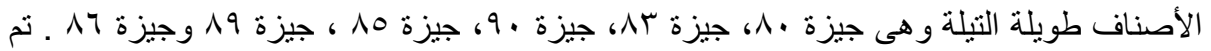

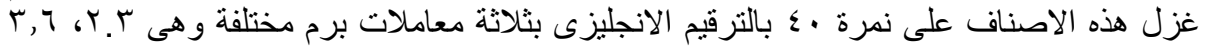

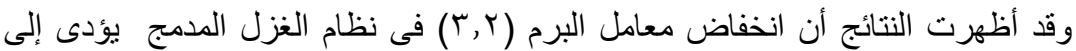



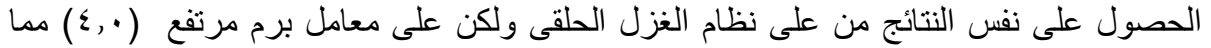

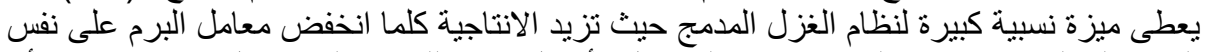

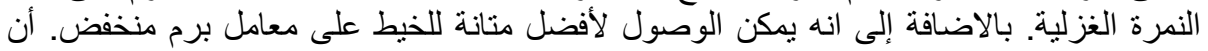

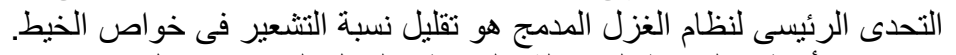

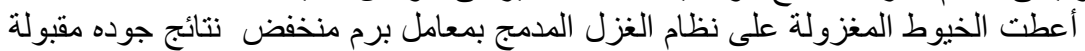

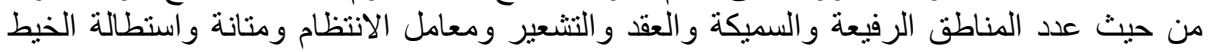

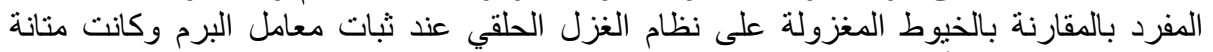

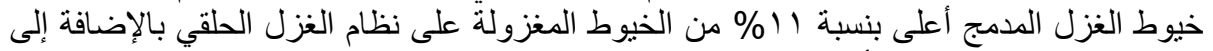

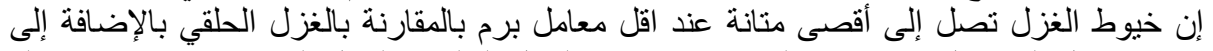


الخيط المفرد بزيادة البرم في كلا النظامين النيط

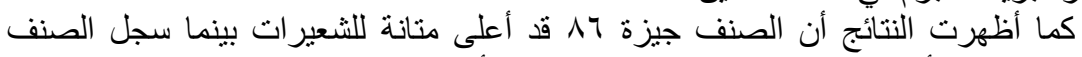
جيزة • 9 اقل انتظام وأعلى تشعبر وذاللك بالمقارنة بباقي الأصناف 
Table (4): Interaction between twist multiplier and spinning system of single yarn properties

\begin{tabular}{|c|c|c|c|c|c|c|c|c|c|c|c|c|c|c|}
\hline \multirow{3}{*}{$\begin{array}{l}\text { Twist } \\
\text { multiplier }\end{array}$} & \multicolumn{14}{|c|}{ Yarn Properties } \\
\hline & \multicolumn{2}{|c|}{ Strength CN/Tex } & \multicolumn{2}{|c|}{ Elongation (\%) } & \multicolumn{2}{|c|}{ CV (\%) } & \multicolumn{2}{|c|}{ Thin places } & \multicolumn{2}{|c|}{ Thick places } & \multicolumn{2}{|c|}{ No. of Neps } & \multicolumn{2}{|c|}{ Hairiness } \\
\hline & Ring & compact & Ring & Compact & Ring & compact & Ring & compact & Ring & compact & Ring & compact & Ring & compact \\
\hline 3.2 & 16.84 & 18.62 & 4.9 & 5.2 & 19,49 & $I V, Y T$ & $9 V$ & r9 & 224 & 124 & 259 & 170 & 5.3 & 4.9 \\
\hline 3.6 & 20.85 & 23.46 & 5.4 & 5.3 & $|v, \varepsilon|$ & 17,97 & 0. & r. & 219 & 132 & 216 & 101 & 5.2 & 5.0 \\
\hline 4.0 & 22.24 & 24.80 & 5.6 & 5.5 & $T, Y \varepsilon$ & $17, \Sigma 7$ & rT & TT & 191 & 68 & 180 & 74 & 4.8 & 4.8 \\
\hline LSD at 0.05 & \multicolumn{2}{|c|}{0.51} & \multicolumn{2}{|c|}{0.23} & \multicolumn{2}{|c|}{0.29} & \multicolumn{2}{|c|}{7.66} & \multicolumn{2}{|c|}{17.06} & \multicolumn{2}{|c|}{ N.S } & \multicolumn{2}{|c|}{0.20} \\
\hline
\end{tabular}

Table (5): Interaction between cotton variety $\mathrm{x}$ twist multiplier $\mathrm{x}$ spinning system on single yarn properties

\begin{tabular}{|c|c|c|c|c|c|c|c|c|c|c|c|c|c|c|c|}
\hline \multirow{3}{*}{ Varieties } & \multirow{3}{*}{$\begin{array}{c}\text { Twist } \\
\text { multiplier }\end{array}$} & \multicolumn{14}{|c|}{ Yarn Properties } \\
\hline & & \multicolumn{2}{|c|}{ Strength CN/Tex } & \multirow{2}{*}{\multicolumn{2}{|c|}{\begin{tabular}{|c|c|}
\multicolumn{2}{|c|}{ Elongation (\%) } \\
Ring compact
\end{tabular}}} & \multicolumn{2}{|c|}{ CV (\%) } & \multicolumn{2}{|c|}{ Thin Places } & \multicolumn{2}{|c|}{ Thick places } & \multicolumn{2}{|c|}{ No. of Neps } & \multicolumn{2}{|c|}{ Hairiness } \\
\hline & & Ring & compact & & & Ring & compact & Ring & Compact & Ring & compact & Ring & compact & Ring & compact \\
\hline \multirow{3}{*}{ Giza 80} & 3.2 & 15.32 & 17.47 & 4.9 & 5.1 & TY,Tr & $19, Y$. & 218 & 70 & 466 & 202 & $4 \cdot 6$ & 351 & 5.4 & 5.3 \\
\hline & 3.6 & 19.44 & 22.35 & 5.6 & 5.3 & $r \cdot, \varepsilon)$ & $11,1 \pi$ & 149 & 41 & 358 & 61 & 331 & 56 & 5.2 & 4.6 \\
\hline & 4.0 & 20.78 & 22.82 & 5.4 & 5.5 & 17.92 & 17.25 & 21 & 30 & 205 & 45 & 157 & 39 & 4.7 & 4.3 \\
\hline \multirow{3}{*}{ Giza 83} & 3.2 & 14.84 & 18.49 & 5.1 & 5.2 & 17,97 & $10, \leq 9$ & 23 & 5 & 121 & 92 & 179 & 67 & 5.5 & 4.9 \\
\hline & 3.6 & 20.78 & 23.09 & 5.6 & 5.3 & 10,90 & $10,1 \mathrm{~V}$ & 8 & 7 & 100 & 80 & 118 & 59 & 5.4 & 4.4 \\
\hline & 4.0 & 21.99 & 23.88 & 5.6 & 5.8 & 10,97 & $1 \leq, \wedge q$ & 16 & 1 & 109 & 60 & 78 & 45 & 4.8 & 4.2 \\
\hline \multirow{3}{*}{ Giza 85} & 3.2 & 17.64 & 20.92 & 4.9 & 5.4 & 11,91 & $17, v \leqslant$ & 55 & 22 & 137 & 82 & 220 & 131 & 5.2 & 4.6 \\
\hline & 3.6 & 21.87 & 24.71 & 5.4 & 5.3 & 10,11 & $17, \leqslant \wedge$ & 19 & 26 & 184 & 195 & 197 & 144 & 5.1 & 4.8 \\
\hline & 4.0 & 23.80 & 26.41 & 5.5 & 5.3 & $1 V, .7$ & $10,0$. & 30 & 3 & 158 & 90 & 175 & 93 & 5.2 & 4.3 \\
\hline \multirow{3}{*}{ Giza 86} & 3.2 & 19.75 & 20.48 & 4.6 & 5.3 & $1 \Lambda, \cdot r$ & $10,1 \varepsilon$ & 41 & 8 & 117 & 86 & 157 & 97 & 5.0 & 4.8 \\
\hline & 3.6 & 22.52 & 25.52 & 5.0 & 5.3 & $I V, Y$. & $10,1 \varepsilon$ & 22 & 9 & 184 & 100 & 187 & 131 & 4.6 & 5.3 \\
\hline & 4.0 & 24.02 & 27.83 & 5.4 & 5.4 & $17, \wedge \mathrm{V}$ & $10, .9$ & 18 & 4 & 178 & 72 & 134 & 78 & 4.8 & 5.0 \\
\hline \multirow{3}{*}{ Giza 89} & 3.2 & 18.59 & 20.05 & 5.1 & 5.0 & 11,07 & 17,09 & 34 & 18 & 154 & 141 & 147 & 149 & 5.2 & 4.9 \\
\hline & 3.6 & 21.54 & 23.97 & 5.7 & 5.1 & $I V, \ldots$ & 17,01 & 14 & 16 & 195 & 116 & 213 & 175 & 5.0 & 5.4 \\
\hline & 4.0 & 22.53 & 26.14 & 5.9 & 5.5 & $I V, Y T$ & $17,1 \mathrm{~V}$ & 16 & 21 & 209 & 128 & 203 & 137 & 4.5 & 5.1 \\
\hline \multirow{3}{*}{ Giza 90} & 3.2 & 14.89 & 14.14 & 4.9 & 5.3 & $r), \leqslant V$ & $19,0 \leqslant$ & 219 & 111 & 347 & 139 & 445 & 225 & 5.7 & 4.8 \\
\hline & 3.6 & 18.94 & 21.13 & 5.4 & 5.4 & $I \Lambda, V V$ & 19,00 & 87 & 83 & 291 & 276 & 250 & 42 & 5.6 & 5.6 \\
\hline & 4.0 & 20.34 & 21.73 & 5.6 & 5.5 & 19,79 & 19,19 & 91 & 97 & 283 & 14 & 335 & 51 & 5.2 & 5.4 \\
\hline \multicolumn{2}{|c|}{ LSD at 0.05} & \multicolumn{2}{|c|}{$1, Y 7$} & \multicolumn{2}{|c|}{$\cdot, 00$} & \multicolumn{2}{|c|}{$\cdot, V Y$} & \multicolumn{2}{|c|}{$11, v_{0}$} & \multicolumn{2}{|c|}{$\leqslant 1, v \wedge$} & \multicolumn{2}{|c|}{39.70} & \multicolumn{2}{|c|}{0.50} \\
\hline
\end{tabular}


J. Agric. Sci. Mansoura Univ., 33 (7), July, 2008

4771 